\title{
DOSEN BAHASA ARAB DAN KOMPETENSINYA DALAM MENGAKTUALISASIKAN TEKNIK PEMBELAJARAN INTERAKTIF
}

\author{
Alinis Ilyas \\ alinisilyas@gmail.com
}

Universitas Islam Negeri (UIN) Raden Intan Lampung

\begin{abstract}
Penelitian ini mengkaji tentang "Dosen Bahasa Arab dan Kompetensinya dalam Mengaktualisasikan Teknik Pembelajaran Interaktif, dengan fokus per-soalan bagaimana dosen bahasa Arab dan kompetensinya dalam mengaktua-lisasikan teknik pembelajaran interaktif bagi mahasiswa pendidikan bahasa Arab (PBA) UIN Raden Intan Lampung?. Sementara tujuan penelitian ini adalah mengekplorasi dosen bahasa Arab dan kompetensinya dalam mengaktualisasikan teknik Pembelajaran bahasa Arab interaktif bagi mahasiswa jurusan pendidikan bahasa Arab (PBA) UIN Raden Intan Lampung. Adapun kontribusi positif yang dapat dihadirkan dari penelitian ini adalah merupakan kontribusi positif yang dapat digunakan oleh para dosen bahasa Arab dalam mengaktualisasikan teknik pembelajaran bahasa Arab interaktif; sebagai paradigma baru dalam meng-aktualisasikan teknik pembelajaran bahasa Arab interaktif terkait dengan kom-petensi dosen bahasa Arab dalam pembelajaran unsur dan empat keterampilan berbahasa; menumbuhkan dan melatih kompetensi bahasa mahasiswa dalam mempelajari bahasa Arab interaktif; dan menghadirkan kontribusi pemikiran bagi Jurusan Pendidikan Bahasa Arab (PBA) UIN Raden Intan Lampung dalam meningkatkan kompetensi dosen bahasa Arab.Mencermati statement di atas, maka jenis penelitian yang digunakan adalah penelitian kualitatif yaitu penelitian yang digunakan untuk meneliti pada kondisi objek natural, di mana peneliti sebagai instrumen kunci, dengan teknik pengum-pulan datanya (observasi, wawancara dan catatan dokumen) dilakukan secara trianggualasi, sementara data yang dihasilkan bersifat deskriptif, dan analisisnya secara induktif. Selanjutnya, hasil penelitian kualitatif ini, lebih menekankan makna dari pada generalisasi. Sedangkan langkah teknik analisis data penelitian kualitatif ini, dapat direalisasikan melalui tiga langkah, yaitu data reduction, data display dan data verification.Menganalisis paparan di atas, maka temuan penelitian yang diperoleh adalah kompetensi dosen dalam mengaktualisasikan teknik interaktif dalam pembelajaran unsur dan empat keterampilan berbahasa, terkait dengan mendesain tujuan, materi, pendekatan, metode, teknik, media dan evaluasi pembelajaran.
\end{abstract}

Kata kunci: Dosen Bahasa Arab, Kompetensi, dan Teknik Pembelajaran Interaktif.

\section{PENDAHULUAN}

Penelitian ini diawali dengan persoalan, yaitu: Bagaimana dosen bahasa Arab dan kompetensinya dalam mengaktualisasikan teknik pembelajaran inter-aktif bagi mahasiswa jurusan pendidikan bahasa Arab (PBA) UIN Raden Intan Lampung?, dimana dosen adalah salah satu komponen dalam proses pembe-lajaran, yang ikut berperan dalam usaha pembentukan sumber daya manusia yang potensial dibidang pembangunan. Oleh karena itu dosen yang merupakan salah satu unsur dibidang kependidikan harus berpartisipasi aktif dan menempatkan posisinya sebagai tenaga yang kompeten. Term ini tentunya terkait dengan proses pendidikan maksimal. Pendidikan maksimal dimaksud adalah pendidikan yang mengutamakan 
peningkatan kemampuan penerapan ilmu pengetahuan. ${ }^{1}$ Di sisi lain seorang dosen ${ }^{2}$ kompeten bukan saja memiliki jiwa mengajar, akan tetapi lebih dari sekedar itu, yaitu harus memiliki jiwa mendidik, karena mendidik adalah memimpin mahasiswa yang meliputi semua tindakan mengenai gejala-gejala pendidikan. Dosen dapat memimpin mahasiswanya dengan mempengaruhi melalui faktor ekstern. Sedangkan faktor intern dari pribadi mahasiswa yang cukup berpengaruh, demikian pula pada perkembangan kejiwaannya.

Paparan lebih jauh ditegaskan bahwa keberhasilan pendidikan tidak terlepas dari proses yang dilakukan, untuk itu perlu diadakan peningkatan mutu pendidikan, salah satu upaya itu perlu mengubah teknik pembelajarannya melalui kompetensi yang dimilikinya, dengan persepsi bahwa pendidikan mampu mengaktualisasikan pengertian (understanding development) bukan sekedar menuangkan informasi dan

${ }^{1}$ IAIN Raden Intan, Pedoman Jabatan Fungsional Dosen dan Angka Kreditnya, Bandar Lampung, 2004, h. 2

${ }^{2}$ Dosen adalah pendidik profesional dan ilmuwan dengan tugas utama mentrans formasi-kan, mengembangkan, dan menyebarluaskan ilmu pengetahuan, teknologi, dan seni melalui pen-didikan, penelitian, dan pengabdian kepada masyarakat. (Wikipedia). hafalan belaka. ${ }^{3}$ Selanjutnya, keberhasilan belajar mahasiswa tidak hanya ditentukan oleh institusi, pola, struktur dan isi kurikulum, karena sebagian besar ditentukan oleh kompetensi dosen yang mengajar dan membimbing mereka. ${ }^{4}$ Oleh sebab itulah jabatan dosen merupakan profesi yang membutuhkan keahlian/kompetensi dan tidak dapat dilakukan oleh sembarang orang di luar bidang pendidikan. ${ }^{5}$ Dosen sebagai pengajar harus mampu menciptakan lingkungan belajar yang efektif, interaktif, menyenangkan serta mampu mengelola kelas dengan baik. Kompetensi seorang dosen merupakan suatu keniscayaan dalam mewujudkan institusi berbasis pengetahuan, yaitu pemahaman tentang pembelajaran, kurikulum dan perkembangan manusia termasuk gaya belajar. ${ }^{6}$ Relevan dengan konteks tersebut, maka Undang-Undang Sisdiknas No 20 tahun 2003, bahwa kompetensi pendidik meliputi: Kompetensi Kepribadian, Kompetensi Pedagogik, Kompetensi Sosial dan Kompetensi

${ }^{3}$ H.R. Tilaar, Perubahan Sosial dan Pendidikan, Bandung: Angkasa, 1998, h.389.

${ }^{4}$ Oemar Hamalik, Pendidikan Guru Berdasarkan Pendekatan Kompetensi, Jakarta: Bumi Aksara, 2002, h 36.

${ }^{5}$ H. Hamzah B.Uno, Profesi Kependidikan, Problema, Solusi dan Reformasi Pendidikan Di Indonesia, Jakarta: Bumi Aksara, 2007, h. 15.

${ }^{6}$ Ibid., h.18. 
Profesional. $^{7}$ Selain keempat kompetensi tersebut, ada tiga kompetensi lain yang niscaya dimiliki oleh dosen bahasa Arab secara spesifik, yaitu kompetensi kebahasaan, kompetensi komunikatif dan kompetensi kebudayaan. ${ }^{8}$

Berdasarkan statement di atas, maka peran dosen sebagai pengelola proses pembelajaran harus memiliki minimal empat kompetensi, yaitu kompetensi merencanakan sisitem pembelajaran, kompetensi melaksanakan sistem pembelajaran, kompetensi mengevaluasi sistem pembelajaran, dan kompetensi merealisasikan sisitem pembelajaran. h. 8 .

${ }^{7}$ Undang-Undang Sisdiknas Tahun 2003,

${ }^{8} \mathrm{Abdu}$ al-Rahman Ibn Ibrahim al-Fauzan, et.al.,(2007) merumuskan tujuan dalam pengantar bukunya: agar peserta didik memiliki kompetensi kebahasaan, kompetensi komunikatif dan kompetensi kebudayaan. Kompetensi kebahasaan mencakupdua aspek, yaitu; (1) keterampilan berbahasa yang terdiri dari: (a) keterampilan mendengar; (b) keterampilan berbicara; (c) keterampilan membaca; dan (d) keterampilan menulis.; dan (2) penguasaan terhadap komponen bahasa yang meliputi: (a) bunyi bahasa; (b) kosakata; dan (c) gramatika. Selanjutnya Kompetensi komunikatif adalah kemampuan berkomunikasi dengan penutur asli dalam konteks sosial, hal ini memungkinkan bagi peserta didik mampu berinteraksi dengan penutur asli, baik secara lisan maupun secara tulisan, di samping mampu mengekspresikan dirinya secara layak dalam berbagai posisi sosial. Berikutnya Kompetensi kebudayaan adalah pemahaman terhadap budaya bahasa dalam berbagai dimensi, dalam terminologi ini adalah budaya Arab dan Islam, di samping pola-pola budaya universal yang tidak bertentangan dengan Islam. (Abdurrahman Ibn Ibrahim al-Fauzan, alArabiyah Baina Yadaik: Silsilah Fi Ta'lim alLughah al-Arabiyah Li Ghair al-Nathiqina Biha,
Paparan detail keempat dimensi kompetensi dimaksud adalah sebagai berikut:

1. Merencanakan Sistem Pembelajaran

a. Merumuskan tujuan;

b. Memilih prioritas materi yang akan diajarkan;

c. Memilih dan menggunakan metode;

d. Memilih dan menggunakan sumber belajar yang ada;

e. Memilih dan mengunakan media.

2. Melaksanakan Sistem pembelajaran

a. Memilih bentuk kegiatan pembelajaran yang tepat;

b. Menyajikan urutan pembelajaran secara tepat.

3. Mengevaluasi Sistem Pembelajaran

a. Memilih dan menyusun jenis evaluasi;

b. Melaksanakan kegiatan evaluasi sepanjang proses;

c. Mengadministrasikan hasil evaluasi.

4. Merealisasikan Sistem Pembelajaran

a. Mengoptimalkan potensi mahasiswa;

b. Meningkatkan wawasan kemampuan diri sendiri;

c. Merealisasikan program pembelajaran lebih lanjut. ${ }^{9}$

Sedangkan menurut pandangan Islam dosen yang kompeten adalah yang memenuhi beberapa kriteria yaitu:

a. Harus menguasai bidang keilmuan, pengetahuan dan keterampilan yang akan diajarkan kepada mahasiswa;

b. Seorang dosen yang kompeten harus memiliki kemampuan

Riyad: al-Mamlakah al-Arabiyah al-Su'udiyah, 2007, Cet.ke-3, h. ث).

${ }^{9}$ Ibid., h.20. 
menyampaikan pengetahuan yang dimilikinya secara baik;

c. Sebagai dosen yang kompeten harus memiliki kepribadian dan budi pekerti yang mulia dan dapat memberi dorongan kepada mahasiswanya untuk mengamalkan ilmu yang telah diajarkan serta dosen tersebut dapat dijadikan panutan. ${ }^{1}$

Memahami term di atas, maka dosen dapat dikatakan kompeten bila ia menguasai dan mampu mengaktualisasikan

keahlian/kompetensinya terhadap mahasiswa yang akan diajarnya, di samping memiliki kepribadian untuk dijadikan suritauladan bagi mereka. Dalam konteks pembelajaran Bahasa Arab, maka dosen bahasa Arab harus menguasai ilmu bahasa Arab (unsur bahasa) dan (keterampilan berbahasa) serta teknik pembelajaran interaktif yang akan diaktualisasikan kepada mahasiswa. Lebih lanjut ditegaskan bahwa dalam proses pembelajaran seorang dosen bahasa Arab harus menguasai empat keterampilan berbahasa yaitu:

1. Seorang dosen harus mahir dalam Istima'

2. Seorang dosen harus mahir dalam Kalam

3. Seorang dosen harus mahir dalam Qira'ah
4. Seorang dosen harus mahir dalam Kitabah. ${ }^{1}$

Adapun tujuan fital, mengapa kompetensi itu harus di bangun serta harus dimiliki oleh dosen bahasa Arab, karena bidang studi bahasa Arab adalah bidang studdi hantu yang terhitung sulit dan rumit, sehingga dosen kompeten merupakan syarat mutlak yang tidak bisa ditawar-tawar lagi. Tujuannya adalah agar target yang diharapkan dapat tercapai secara maksimal. Lebih jauh dipaparkan bahwa dosen bahasa Arab yang kompeten itu harus dapat meningkatkan teknik pembelajaran interaktif relevan dengan metode pembelajaran bahasa Arab. Pengertian teknik dimaksud adalah "pelaksanaan secara operasional suatu metode dalam proses pembelajaran."1 Mahmud Kamil al-Naqoh mendefinisikan teknik sebagai rencana, pengaturan, dan fasilitas yang secara faktual memiliki posisi di dalam kelas dan dipergunakan untuk merealisasikan tujuan dari suatu proses $\quad$ pembelajaran. ${ }^{1}$ Sedangkan Mulyanto mengekspresikan bahwa teknik

${ }^{1}$ Abuddin Nata, Paradigma ${ }^{0}$ Pendidikan Islam, Jakarta: Grasindo, 2001,Cet.ke-1, h.138.

${ }^{1}$ Ahmad Fuad Efendy, ${ }^{1}$ Metodologi Pengajaran Bahasa Arab, Malang: Misykat, 2005, Cet.ke-2, h. 102-137

${ }^{1}$ Ibid, h. 78

${ }^{1}$ Mahmud Kamil Al-Naqoh, ${ }^{3}$ Ta'lim alLughah li al-Nathiqin bi al-Lughat Ukhro:Ususuhu Madakhilu-Thuruq Tadrisuh 
bersifat implementasional, artinya apa yang terjadi di dalam kelas atau "strategi" untuk mencapai sasaran. Teknik tergantung kepada dosen, imajinasi, kreatifitas serta komposisi kelas. Kegunaan dari berbagai macam teknik ini dalam pembelajaran bahasa Arab banyak tergantung pada metode dan approach (pendekatan). ${ }^{1}$

Sementara itu untuk merealisasikan teknik pembelajaran bahasa agar lebih baik, maka Djago Tarigan dan H.G. Tarigan mengekspresikan bahwa "seorang dosen harus menguasai materi serta mampu menguasai metode dalam rangka mengajarkan materi kepada mahasiswanya,"1 Pengetahuan terhadap5 variatifitas teknik pembelajaran dan kemampuan untuk mempraktekkannya sangat membantu dosen bahasa Arab dalam mengaktualisasikan proses pembelajaran keterampilan berbahasa. Aneka keuntungan tersebut dapat dipaparkan secara detail berikut ini:

1. Membuat pengajaran lebih bervariasi dan lebih menarik;

2. Dapat memecahkan berbagai masalah seperti jumlah mahasiswa yang terlalu banyak, perbedaan kemampuan

Makkah al Mukarromah, Jami'ah al-Um al-Qura, 1985, h. 51

${ }^{1}$ Mulyanto Sumardi, Pengajaran Bahasa Asing: Sebuah Tinjauan dari Segi Metodologi, Jakarta, Bulan Bintang, 1975, h. 13-14.

${ }^{1}$ Djago Tarigan dan H.G. Taŕigan, Teknik Keterampilan Berbahasa, Angkasa, Bandung, 1988, Cet.ke-1, h. 29. individual, materi dan lingkungan belajar yang kurang menarik;

3. Dosen lebih percaya diri dalam mengajar;

4. Dosen dapat menyampaikan materi pembelajaran lebih tepat;

5. Menghidupkan suasana proses pembelajaran;

6. Mahasiswa senang belajar dan guru senang mengajar;

7. Memancing pemusatan perhatian mahasiswa terhadap pelajaran. ${ }^{1}$

Dari beberapa paparan di atas, dapat ditarik benang merah bahwa teknik pembelajaran bahasa Arab secara spesifik adalah tatacara penyajian bahan ajar/materi terhadap mahasiswa sesuai dengan metode dan pendekatan, karena ketiga aspek tersebut memiliki hubungan hirarkis yang tidak bisa dipisahkan satu sama lainnya. Sementara dalam tataran realisasi dan aktualisasinya tergantung kepada dosen bahasa Arab itu sendiri. Jika teknik pembelajaran bahasa Arab dimaksud dioperasionalkan sesuai metode pembelajaran, maka teknik itu akan menjadi baik, dengan terminologi yang lebih populer bahwa teknik pembelajaran bahasa Arab adalah merupakan implementasi langkah-langkah dalam sebuah metode pembelajaran bahasa. Sehingga Proses Pembelajaran Bahasa Arab Interaktif akan terjadi secara maksimal.

1 Ibid., h.38-41 
Mengacu kepada term di atas, maka sebagai data awal penelitian ini penulis mengadakan pengamatan langsung proses pembelajaran bahasa Arab pada Jurusan Pendidikan Bahasa Arab UIN Raden Intan lampung. Dari hasil observasi, tampaknya Dosen bahasa Arab pada institusi tersebut kurang optimal dalam merealisasikan pembelajaran keterampilan berbahasa Arab terhadap mahasiswa. Hal ini terlihat kurang memberikan motivasi dan menjadikan kondisi pembelajaran tidak interaktif serta tidak menyenangkan. Di sisi lain teknik dalam mengajarkan bahan ajar/materi bahasa Arab terhadap mahasiswa kurang bervariasi, seperti dalam proses pembelajaran dosen menggunakan metode qawa'id tarjemah, dosen hanya membacakan dan menterjemahkan teksteks yang ada pada buku ajar, tanpa memperhatikan kompetensi mahasiswa dalam memahami materi tersebut. Begitu pula pada pembelajaran keterampilan berbahasa sektor keterampilan istima atau maharat istima', mahasiswa kurang optimal dalam pengucapan dan berlatih kata dan kalimat. ${ }^{1}$ Sementara itu, indikator yang dapat dijadikan dasar dari

${ }^{1}$ Hasil observasi pertama Peneliti pada tanggal 08 April 2017 dalam Proses Pembelajaran Maharat al-Istima' pada gedung Jurusan Pendidikan Bahasa Arab UIN Raden Intan Lampung. hasil observasi, bahwa tiga orang dosen bahasa Arab pada Jurusan Pendidikan Bahsa Arab (PBA) kurang kompeten, dibuktikan dengan kurang mampu berbahasa arab aktif, di samping penguasaan terhadap metodologi pembelajaran, apalagi untuk merealisasikan teknik pembelajaran interaktif. Hal ini disebabkan latar belakang mereka adalah alumni Fakultas Adab dan kurang membiasakan di dalam mengaplikasikan proses pembelajaran pada jurusan Pendidikan Bahasa Arab dengan menggunakan bahasa Arab aktif. ${ }^{1}$ Sedangkan penguasaan konten materi tidak diragukan, bahkan mereka sangat menguasai secara detail melebihi para dosen metodologi pembelajaran lainnya. Padahal secara faktual, al-Lughah 'adah, wa al-'adatu Tuktasabu ila al-Tikrar. (Bahasa itu adalah kebiasaan, dan kebiasaan itu membutuhkan repititif/berulang-ulang).

Berdasarkan hasil pengamatan ini, maka dapat dicermati bahwa kondisi pembelajaran yang diaktualisasikan dosen bahasa Arab pada jurusan Pendidikan Bahasa Arab UIN Raden Intan Lampung masih kurang variatif dan sangat

${ }^{1}$ Hasil observasi kedua Pe̊neliti pada tanggal, 15 April 2017 dalam Kondisi Proses Pembelajaran Maharat al-Kalam di gedung Jurusan Pendidikan Bahasa Arab UIN Raden Intan Lampung. 
konvensional, sementara mengajarkan bahasa berarti mengajarkan keterampilan berbahasa itu sendiri. Artinya bagaimana mungkin mahasiswa dapat berbahasa dengan aktif, di samping mengajarkan tentang bahasa yang dipelajari meliputi gramatika dan ilmu yang melingkupinya. Konteks ini dapat dibuktikan dengan fakta di lapangan yang menjadi objek penelitian yaitu Mahasiswa Jurusan Pendidikan Bahasa Arab UIN Raden Intan Lampung. Data mahasiswa menunjukkan skor rata-rata cukup dalam mata kuliah keterampilan berbahasa. Hal ini, merupakan data mahasiswa tahun pembelajaran 2015-2016 semster genap (semester dua: 64,21; semester empat: 63,73; semester enam: 62,86), kendati proses pembelajaran berlangsung kurang optimal. Dengan demikian persoalan yang muncul kemudian adalah apakah dosen bahasa Arab dapat dikatakan kompeten, jika tidak maksimal mengaktualisasikan teknik pembelajaran interaktif? term ini sangat menarik dan urgen untuk dikaji secara ilmiah dalam penelitian ini.

\section{METODE PENELITIAN}

Jenis Penelitian yang digunakan dalam penelitian ini adalah penelitian kualitatif. ${ }^{1}$ Term ini dipandang ${ }^{9}$ cocok karena bersifat alamiah dan menghendaki keutuhan sesuai dengan persoalan penelitian yaitu dosen bahasa Arab dan kompetensinya dalam mengaktualisasikan teknik pembelajaran interaktif bagi mahasiswa pendidikan bahasa Arab (PBA) UIN Raden Intan Lampung. Selanjutnya, dalam penelitian ini yang diamati dan diwawancarai adalah manusianya, yaitu para pengelola pendidikan, peserta didik, dan orang tua mereka, tokoh masyarakat sekitar dan relasi lain yang menjalankan aktivitas kerjanya terkait dengan dosen bahasa Arab dan kompetensinya dalam merealisasikan teknik pembelajaran interaktif bagi mahasiswa pendidikan bahasa Arab (PBA) UIN Raden Intan Lampung.

Dalam teknik pengumpulan data ini, peneliti akan menggunakan tiga

${ }^{1}$ Menurut Sugiyono penelitiån kualitatif adalah penelitian yang digunakan untuk meneliti pada kondisi objek natural, di mana peneliti sebagai instrumen kunci, dengan teknik pengumpulan datanya dilakukan secara trianggualasi, sementara data yang dihasilkan bersifat deskriptif, dan analisisnya secara induktif. Sedangkan hasil penelitian kualitatif ini, lebih menekankan makna dari pada generalisasi. (Sugiyono, Metode Penelitian Admimstrasi, Bandung: Alfabeta, 2002, Cet. ke-2, h. 4.). Pada dasarnya, penelitian kualitatif mencermati manusia dalam linkungan hidupnya, berinteraksi dengan mereka, berusaha memahami bahasa dan tafsiran mereka tentang dunia sekitarnya. (Nasution, Metode Research: Penelitian Ilmiah, Jakarta: Bumi Aksara, 1996, Cet. ke -1, h. 5.). 
format, yaitu pengamatan berperan serta (participant observation); wawancara mendalam (indepth interview); catatan dokumen dan instrument penelitian.

\section{HASIL DAN PEMBAHASAN}

Dalam pembahasan dan analisis data ini, ada tiga dimensi yang perlu diekspresikan secara maksimal, yang diperoleh melalui hasil observasi, wawancara dan catatan dokumen terkait dengan Kompetensi Dosen Bahasa Arab, Teknik Pembelajaran Bahasa Arab Interaktif, serta Unsur dan Empat Keterampilan Berbahasa Arab. Karena ketiga dimensi ini merupakan fokus sentral yang akan dipaparkan serta diaktualisasikan, terkait dengan data konkrit yang dihasilkan dari lapangan. Di samping itu ketiga dimensi ini juga merupakan paradigma baru yang melahirkan persoalan, dan akan dijawab pada kesimpulan penelitian ini. Selanjutnya akan diperoleh temuan baru dari penelitian ini. Untuk memudahkan pemahaman dapat dilihat peta visualisasi kajian dimaksud secara gradual.

\section{A. Kompetensi Dosen Bahasa Arab}

Kompetensi adalah kemampuan kerja setiap individu yang mencakup aspek pengetahuan, keterampilan dan sikap kerja yang sesuai dengan standar yang ditetapkan" Peraturan Pemerintah
(PP) No. 23 Tahun 2004, tentang Badan Nasional Sertifikasi Profesi (BNSP) menjelaskan tentang sertifikasi kompetensi kerja sebagai suatu proses pemberian sertifikat kompetensi yang dilakukan secara sistimatis dan objektif melalui uji kompetensi yang mengacu kepada standar kompetensi kerja nasional Indonesia dan atau Internasional. Pengertian Competency Based Training (CBT)" Sebuah pendekatan pada pelatihan yang menekankan pada apa yang seorang individu dapat mendemontrasikan: pengetahuannya, ketrampilan serta sikap profesional, di tempat kerja, sesuai dengan standard Industri sebagai hasil dari training". Selanjutnya Standard Kompetensi Kerja Nasional Indonesia (SKKNI), Kompetensi adalah pernyataan tentang bagaimana sesorang dapat mendemontrasikan: keterampilan, pengetahuan dan sikapnya di tempat kerja sesuai dengan standar Industri atau sesuai dengan persyaratan yang ditetapkan oleh tempat kerja (industri).

Jadi dapat disimpulkan bahwa kompetensi adalah sebuah pernyataan terhadap apa yang seseorang harus lakukan ditempat kerja untuk menunjukan pengetahuannya, keterampilannya dan sikap sesuai dengan standar yang dipersyaratkan, disamping itu juga harus 
mencakup lima dimensi dari kompetensi: Task skills- mampu melakukan tugas per tugas; Task management skills- mampu mengelola beberapa tugas yang berbeda dalam pekerjaan; Contingency management skills- tanggap terhadap adanya kelainan dan kerusakan pada rutinitas kerja; Environment skills/job role- mampu menghadapi tanggung jawab dan harapan dari lingkungan kerja/ Beradaptasi dengan lingkungan; Transfer skills- Mampu mentransfer kompetensi yang dimiliki dalam setiap situasi yang berbeda (situasi yang baru/ tempat).

Konteks di atas, didukung oleh Undang-undang Guru dan Dosen telah mengisyaratkan tentang beberapa kompetensi yang harus dimiliki oleh seorang dosen yaitu, Kompetensi kepribadian, Kompetensi Pedagogik, Kompetensi Sosial dan kompetensi profesional. Sementara di dalam pemebelajaran bahasa Arab seorang dosen harus memiliki tiga kompetensi, yaitu kompetensi kebahasaan, kompetensi komunikatif dan kompetensi kebudayaan. Keberhasilan seorang dosen bahasa Arab dalam menjalankan profesinya sangat ditentukan oleh ketiga kompetensi tersebut dengan penekanan pada kemampuan merealisasikan pembelajaran.

Mencermati undang-undang dimaksud, maka kompetensi pribadi adalah sikap pribadi dosen berjiwa pancasila yang mengutamakan budaya bangsa Indonesia, yang rela berkorban bagi kelestarian bangsa dan negaranya. Kompetensi profesional adalah kemampuan dalam penguasaan akademik (mata pelajaran/bidang studi) yang diajarkan dan terpadu dengan kemampuan mengajarnya sekaligus sehingga dosen itu memiliki wibawa akademis. Sementara kompetensi kemasyarakatan (sosial) adalah kemampuan yang berhubungan dengan bentuk partisipasi sosial. ${ }^{2}$ Mengacu kepada hasil obserasi dan wawancara peneliti dengan tiga dosen mata kuliah bahasa Arab terkait dengan dosen bahasa arab dan kompetensinya dalam mengaktualisasikan teknik pembelajaran interaktif mencakup sepuluh dimensi yang harus di penuhi oleh mereka, yaitu: merealisasikan kepribadian; menguasai landasan kependidikan; menguasai bahan pelajaran; menyusun program pengajaran; melaksanakan program pengajaran; menilai hasil dalam PBM yang telah dilaksanakan; menyelenggarakan penelitian sederhana untuk keperluan pengajaran; menyelenggarakan program bimbingan; berinteraksi dengan sejawat

2 Sahertian, Piet dan Ida Alieda, Supervisi Pendidikan dalam Rangka Program Inservice Education, Jakarta: Rineka Putra, 2013, h. 20 
dan masyarakat; serta menyelenggarakan administrasi sekolah. ${ }^{2}$ Data ini diperkuat oleh teori Surya Muhammad bahwa dosen kompeten akan tercermin dalam pelaksanaan pengabdian tugas-tugas yang ditandai dengan keahlian baik materi maupun metode, selain itu juga ditunjukkan dengan tanggung jawabnya dalam melaksanakan seluruh pengabdiannya. ${ }^{2}$ Suatu pekerjaan yang ditopang oleh kompetensi membutuhkan persyaratan khusus yakni: (1) menuntut adanya keterampilan berdasarkan konsep dan teori ilmu pengetahuan yang mendalam. (2) menekankan pada suatu keahlian dalam bidang tertentu sesuai dengan profesinya; (3) menuntut adanya tingkat pendidikan yang memadai; (4) adanya kepekaan terhadap dampak kemasyarakatan dari pekerjaan yang dilaksanakannya; (5) memungkinkan perkembangan sejalan dengan dinamika kehidupan. ${ }^{2}$ Di samping itu, data dî atas

${ }^{2}$ Hasil Observasi dan Wawancara Peneliti dengan beberapa orang Dosen Pendidikan Bahasa Arab UIN Raden Intan Lampung, tanggal, 04 September 2017 terkait dengan Kompetensi Dosen Bahasa Arab dalam Mengaktualisasikan Teknik Pembelajaran Bahasa Arab Interaktif terhadap Mahasiswa Pendidikan Bahasa Arab UIN Raden Intan Lampung.

${ }^{2}$ Surya Muhammad, ${ }^{2}$ Membangun Profesionalisme Guru, Makalah Seminar Nasiona Pendidikan, Jakarta, 6 Mei 2005, di akses, 13 Januari 2017.

${ }^{2}$ Moh.Ali, 2005, dalam Kunảndar, Guru Profesional ,Implementasi KTSP dan Persiapaan Menghadapi Sertifikasi Guru, Jakarta: PT Raja Grasindo Persada, 2007, h. 47. diperkuat juga oleh Kunandar (2007), mengekspresikan bahwa dosen yang kompeten dituntut memiliki persyaratan minimal antara lain, memiliki kualifikasi pendidikan profesi yang memadai, memiliki kompetensi keilmuan sesuai dengan bidang yang ditekuninya, memiliki kemampuan berkomunikasi yang baik dengan mahasiswanya, mempunyai jiwa kreatif dan produktif, mempunyai etos kerja dan komitmen tinggi terhadap profesinya, dan selalu melakukan pengembangan diri secara terus menerus (continous improvement) melalui organisasi profesi, internet, buku, seminar dan semacamnya. ${ }^{2}$

Dari beberapa teori di atas, dapat disimpulkan bahwa dosen bahasa Arab harus kompeten yaitu memiliki kemampuan kualifikasi pendidikan profesi yang memadai, memiliki kompetensi keilmuan sesuai dengan bidang yang ditekuninya dan keahlian khusus dalam bidang keguruan sehingga ia mampu melakukan tugas dan fungsinya sebagai dosen bahasa Arab dengan kemampuan yang maksimal. Dosen bahasa Arab yang kompeten adalah dosen yang terdidik dan terlatih serta memiliki konsep dan teknik pembelajaran yang

$$
{ }^{2} \text { Kunandar, } 4 \quad \text { Guru }
$$
Profesional,Implementasi KTSP dan Persiapaan 
variatif dan interaktif, sehingga menarik dan tidak menjadikan mahasiswa bosan dalam mempelajari bahasa Arab dimaksud.

\section{B. Teknik Pembelajaran Bahasa Arab Interaktif}

Terminologi Teknik adalah adalah: "Pelaksanaan secara operasional suatu metode dalam proses belajar dan mengajar"2 . Menurut Mulyanto, teknik bersifat implementasionil, artinya apa yang sesungguhnya terjadi dalam kelas atau "strategi" untuk mencapai sasaran. Teknik harus sesuai dengan metode dan karena itu tidak boleh bertentangan dengan approach. $^{2}$ Di dalam pembelajaran ketrampilan berbahasa, sesuai dengan namanya, bertujuan untuk menumbuhkan dan mengembangkan keterampilan berbahasa mahasiswa. Terampil berbahasa berarti terampil menyimak, terampil berbicara, terampil membaca dan terampil menulis. Dengan demikian teknik pengajaran keterampilan berbahasa adalah rencana, pengaturan dan fasilitas yang bersifat implementasional untuk menumbuh kembangkan

Menghadapi Sertifikasi Guru, Jakarta, PT Raja Grasindo Persada, 2007, h. 50.

${ }^{2}$ Ahmad Fuad Efendy, ${ }^{5}$ Metodologi Pengajaran Bahasa Arab, Misykat: Malang 2005, Cet.ke-2, h. 6

${ }^{2}$ Mulyanto Sumardi, Pengajáran Bahasa Asing: Sebuah Tinjauan dari Segi Metodologi, Jakarta: Bulan Bintang, 1975, h. 13-14. keterampilan menyimak, berbicara, membaca dan menulis mahasiswa. Hasil obeservasi, wawancara dan cacatatan dokumen peneliti terhadap tiga dosen bahasa Arab jurusan pendidikan bahasa Arab UIN Raden Intan Lampung menegaskan bahwa syarat minimal yang harus dikuasai oleh dosen ialah penguasaan materi dan keterampilan dalam mengajarkannya kepada mahasiswa (teaching skill). Salah satu kelemahan umum pengajaran di dalam kelas terletak dari komponen metodologi pembelajarannya, Para dosen cenderung mengajar secara rutin dan kurang bervariasi dalam penyampaian materi. Padahal hasil belajar berkorelasi positif dengan metode/ teknik pembelajaran yang diikuti cara belajar mahasiswa. ${ }^{2}$

Berdasarkan data di atas, dapat dicermati bahwa dalam pembelajaran bahasa, penguasaan dosen terhadap materi bahasa dan teknik pembelajarannya merupakan hal yang penting. Dosen bahasa Arab harus profesional berarti selain secara khusus memiliki keahlian dan keterampilan khusus meliputi kemahiran dalam seluk-beluk metode,

\footnotetext{
${ }^{2}$ Hasil Observasi, Wawancara ${ }^{7}$ dan Catatan Dokumen Peneliti dengan Zulhannan terkait dengan Teknik Pembelajaran Bahasa Arab Interaktif, secara spesik berkaitan dengan aktualisasi pembelajaran interaktif dalam unsur dan empat keterampilan berbahasa. Pada tanggal, 11 September 2017.
} 
keterampilan berbahasa dan kaya teknik pembelajaran yang mampu pengalaman dengan teknik pembelajarannya. Pemilihan dan pengembangan metode, teknik yang tepat dalam pembelajaran bahasa Arab khususnya, memberikan keuntungan bagi pelak-sanaan proses pembelajaran, di samping suasana yang menarik menimbulkan gairah dan motivasi belajar maksimal, yang berimplikasi kepada peningkatan prestasi belajar yang tinggi. Selanjutnya teknik pembelajaran bahasa arab interaktif pada dasarnya adalah serangkaian upaya yang dilakukan oleh pengajar bahasa Arab untuk membuat proses pembelajaran berjalan sesuai dengan konsep yang sebenarnya. Data tersebut diperkuat oleh teori yang dikemukakan oleh Imam Ma'ruf bahwa dalam pembelajaran interaktif peranan pengajar bukanlah satu-satunya nara sumber dan paling banyak menggunakan waktunya dikelas, artinya pengajar lebih berperan sebagai fasilitator yang bertugas memandu, mendampingi dan memberikan pengarahan kepada para peserta didik agar proses pembelajaran dapat mengarah pada pencapaian tujuan yang diinginkan. $^{2}$ Dengan demikian maka teknik pembelajaran interaktif adalah

2 Imam Ma'ruf, Strategi Pémbelajaran Bahasa Arab Aktif, Semarang: Needs Press, 2009, cet.ke-1, h. 99-100 menciptakan kondisi pembelajaran yang kondusif, innovatif, aktif dan kreatif.

\section{Unsur dan Empat Keterampilan Berbahasa Arab}

Latihan aneka unsur bahasa sangat vital bagi mahasiswa. Hal ini tentunya harus dikuasai, difahami dan diekspresikan, di samping term ini juga sangat membantu mereka di dalam mengaktualisasikannya. ${ }^{2}$ Di antara aneka unsur bahasa dimaksud adalah ashwat, mufradat dan qawa'id. Pengertian pertama, ashwat (bunyi) adalah bekas dari ucapan getaran suara dari suatu objek dan dipindahkan kedalam pusat materi yang sadar dengan rasa suara. Bunyi sendiri dijelaskan oleh kalimat yang mana kalimat adalah bagian dari jumlah sebagai bagan untuk berkomunikasi. Oleh karena itu, suara merupakan dasar bangunan dalam susunan kalimat. Dan mempelajari suara yang pertama kali tentunya yang berkaitan dengan bahasa dan memperhatikanya dengan lebih. ${ }^{3}$ Tentunya dengan bantuan ilmu Ashwat dapat diketahui sedikit banyak kajian

\footnotetext{
${ }^{2}$ Mahmud Isma'il Shini, et.al., Mursyid al Mu'allim fi Tadris al Lughah al Arabiyyah Li Ghairi al Nathiqinabiha - Tathbiqat Amaliyyah Li Taqdim al Durus Wa Ijrak al Tadribat, Riyad, Maktab al Tarbiyah al Arabi, Cet. ke-2, h. 109.

${ }^{3}$ Abdul Wahab Rasyidi, Ilmu al-Ashwat al-Nuthqi, Malang: UIN Malang Press, 2012, Cet.ke-1, h. 1
} 
pembahasan tentang bunyi. Pengertian kedua, mufradat (kosakata) yang dalam bahasa Inggrisnya vocabulary adalah himpunan kata atau khazanah kata yang diketahui oleh seseorang atau entitas lain yang merupakan bagian dari suatu bahasa tertentu.

Mufradat (kosakata) ada yang mendefinisikan sebagai himpunan semua kata-kata yang dimengerti oleh orang tersebut dan kemungkinan akan digunakannya untuk menyusun kalimat baru. Pendapat senada diekspresikan oleh Horn, bahwa mufradat adalah sekumpulan kata yang membentuk sebuah bahasa. Peran kosakata dalam menguasai empat kemahiran berbahasa sangat diperlukan, sebagaimana yang dinyatakan Vallet bahwa kemampuan seseorang untuk memahami empat kemahiran berbahasa tersebut sangat bergantung pada penguasaan kosakata yang dimiliki. Lebih jauh ditegaskan bahwa mufradat merupakan kumpulan kata-kata tertentu yang akan membentuk bahasa. Kata adalah bagian terkecil dari bahasa yang sifatnya bebas. Pengertian ini membedakan antara kata dengan morfem. Morfem adalah datuan bahasa terkecil yang tidak bisa dibagi atas bagian bermakna yang lebih kecil yangmaknanya relatif stabil. Maka kata terdiri dari morfem-morfem. Sedangkan pengertian ketiga, qawa'id adalah deskripsi dari aturan-aturan yang berlaku pada setiap bahasa. Lebih dari itu, qawa'id merupakan suatu subsistem yang terdapat dalam organisasi bahasa dimana satuan-satuan bermakna bergabung untuk membentuk satuansatuan yang lebih besar. Hocket (1958) memberikan defenisi lain bahwa tata bahasa atau qawa'id memuat sistem aturan atau pola-pola yang berlaku pada suatu bahasa. Kaidah-kaidah suatu bahasa diperoleh atas dasar analisis peneliti terhadap peristiwa-peristiwa bahasa yang berulang-ulang. ${ }^{3} \quad$ Brown berpendapat bahwa tata bahasa atau qawa'id adalah suatu sistem aturan yang mempengaruhi susunan dan hubungan konvensional kata-kata alam suatu kalimat. Pengertian ini secara implisit menyatakan adanya unsur-unsur pembentuk kalimat yang menjadi kajian dalam tata bahasa, yaitu tata kata dan tata kalimat. $^{3}$

Akan tetapi aspek ini merupakan parsial dari pembahasan struktur bahasa yang tidak cukup untuk mengakurasikan penguasaan mahasiswa terhadap

${ }^{3}$ Moch. Fauji Herdiansyah, et.al., Makalah Pembelajaran Qowa'id Bahasa Arab, Bandung: UIN Sunan Gunung Djati, Minggu, 15 Nopember 2015, di akses, 10 April 2017.

${ }^{3}$ Ibid. 
keterampilan berbahasa. $^{3} \quad$ Hasil observasi, wawancara dan catatan dokumen peneliti dengan dosen bahasa Arab jurusan Pendidikan Bahasa Arab UIN Raden Intan Lampung terkait dengan keterampilan yang sangat strategis untuk dikuasai oleh mahasiswa adalah keterampilan mendengar, berbicara, membaca dan menulis (Insya). ${ }^{3}$ Dan keempat keterampilan ini memiliki hubungan hirarkis yang tidak bisa dipisahkan satu sama lainnya.

\section{a. Keterampilan Istima'}

Interpretasi istima' adalah seseorang memusatkan pikirannya untuk memperhatikan lawan bicara, dengan tendensi memahami isi kandungan pembicaraannya, di samping mengadakan analisis, dan bahkan bila perlu mengadakan kritikan. $^{3}$ Jadi yang dimaksud mendengar dalam konteks ini adalah bukan hanya mendengarkan pembicara secara pasif, akan tetapi lebih produktif, maksudnya seorang yang sedang mendengar pembicaraan lawan 109.

${ }^{3}$ Mahmud Isma'il Shini, et.aß ., Op.Cit., h.

${ }^{3}$ Hasil Observasi, Wawancara ${ }^{4}$ dan Catatan Dokumen terhadap beberapa dosen bahasa Arab UIN Raden Intan Lampung terkait dengan empat keterampilan berbahasa dengan mengaktualisasikan teknik pembelajaran interaktif, tanggal, 15 September 2017.

${ }^{3}$ Nasir Abdullah al Ghani ${ }^{5}$ dan Abdul Hamid Abdullah, Usus I'dad al Kutub al Ta'limiyyah Li Ghairi al Nathiqinabiha bi al Arabiyyah, Dar al I'tisham, Tanpa Tahun, h. 51. harus mampu mengkorelasikan simbol dan argumentasi yang diekspresikan oleh sipembicara tadi, serta mengadakan analisis sejauh mana kebenaran dan kevaliditasan argumentasi yang dikemukakan.

Di samping itu keterampilan mendengar dapat dicapai melalui beberapa latihan, yaitu mendengarkan aneka perbedaan bunyi unsur kata (fonem) dengan unsur kata lainnya berdasarkan makhraj huruf yang benar, baik langsung dari penutur asli maupun melalui rekaman tape/piringan hitam. Di sisi lain, keterampilan mendengar ini dapat dicapai melalui nuansa latihan unsur kata yang terpisah dari pemahaman arti maupun bunyi kata dan kalimat dengan pemahaman arti yang terkandung.

\section{b. Keterampilan Kalam}

Interpretasi kalam disini adalah mengucapkan bunyi-bunyi Arab secara benar. Bunyi-bunyi tersebut keluar dari makharij al-huruf yang telah menjadi konsensus pakar Bahasa. ${ }^{3}$ Keterampilan berbicara ini dapat dicapai melalui beberapa latihan (praktek) dari apa yang didengar secara pasif dalam latihan mendengar. Tanpa latihan lisan secara intensif, maka sangat sulit bagi mahasiswa untuk mencapai penguasaan

${ }^{3}$ Ibid., h. 54. 
bahasa Arab secara sempurna. Salah satu teknik latihan untuk mencapai kemampuan keteram-pilan berbahasa lisan secara efektif---maksudnya dari yang sederhana sampai kepada yang rumit---adalah dengan menggunakan latihan pola kalimat (al-Tamarin bi alNamazij), istilah lain yang lebih populer adalah (Pattern Drill). ${ }^{3}$

\section{c. Keterampilan Qira'ah}

Qira'ah adalah salah satu faktor yang sangat urgen di dalam membina kepri-badian seseorang, disamping memberikan motivasi tersendiri. Dengan membaca, oto-matis seseorang mendapatkan pengetahuan dan pengalaman. $^{3}$ Jadi tanpa memb̊aca jangan bermimpi seseorang dapat memperluas wawasan dan paradigma berfikir, apa-lagi mendapatkan ilmu pengetahuan dan pengalaman yang memadai. Di dalam keterampilan membaca ini, ada 2 aspek yang menjadi titik sentralnya, Pertama, mengenal simbol-simbol tertulis. Dan Kedua, mamahami isi tulisan (karangan). Yang dimaksud mengenal sismbol-simbol tertulis adalah mahasiswa dikenalkan alfabet Arab terlebih dahulu, sebab sistem

\footnotetext{
${ }^{3}$ Data hasil Observasi Peñeliti dalam kondisi proses pembelajaran di runag kelas pendidikan bahasa Arab UIN Raden Intan Lampung, tanggal, 18 September 2017.
}

penulisannya berbeda dengan alfabet latin. Sedangkan yang dimaksud dengan memahami isi tulisan adalah memperkenalkan terhadap mahasiswa kata-kata baru dari bacaan tersebut dengan memberi syakal (hal ini khusus bagi siswa pemula). Disamping itu mahasiswa dibekali perbendaharaan yang củkup, terutama yang sudah termasuk perbendaharaan bahasa Indonesia, seperti : Kursi, Mistar, Kitab dan lain-lain. ${ }^{3}$

\section{d. Keterampilan Kitabah}

Kitabah adalah suatu aktivitas yang sangat rumit untuk direalisasikan, oleh sebab itu untuk dapat menulis dengan baik merupakan persoalan yang sangat sulit dicapai. ${ }^{4}$ Kendati kasus ini sangat sulit, masih dapat dicermati melalui kesungguhan dan ke-uletan. Adapun yang dimaksud keterampilan menulis disini adalah keterampilan di da-lam mengekspresikan pikiran dan perasaan yang dituangkan dalam bentuk tulisan (karangan). bagi tingkat pemula dapat direalisasikan melalui Guided Composition (me-ngarang terbimbing), kemudian diadakan bimbingan secara

\footnotetext{
${ }^{3}$ Ibid., h. 57

${ }^{3}$ Hasil Wawancara Peneliti dengan dosen bahasa Arab Jurusan Pendidikan Bahasa Arab (Zulhanan) terkait dengan aktualisasi teknik pembelajaran interaktif keterampilan Qira'ah bagai Mahasiswa Pendidikan Bahasa Arab, tanggal, 18 September 2017.

${ }^{4}$ Ibid., h, 63.
} 
gradatif, hingga akhirnya berkembang menjadi Free Composition (mengarang bebas). Contoh konkrit mengarang terbimbing adalah mahasiswa diperintahkan untuk menyalin kalimat, memodivikasi kalimat, mengganti salah satu unsur dalam kalimat (takmilah aljumlah) dan lain sebagainya.

Sedangkan contoh konkrit mengarang bebas adalah mahasiswa diberi kebebasan untuk menulis sebuah karangan dengan kosa kata dan pola kalimat yang bebas (tanpa ada ketentuan dari dosen). Hal ini tentunya berkaitan dengan persoalan-persoalan yang sudah dikenal mahasiswa, seperti: menulis tentang aktivitas bangun tidur, pergi ke pasar, korespondensi dan lain-lain.

\section{SIMPULAN DAN SARAN}

Mencermati paparan di atas, maka peneliti dapat menyimpulkan bahawa Dosen bahasa Arab dan kompetensinya dalam mengaktualisasikan teknik pembelajaran interaktif bagi mahasiswa jurusan pendidikan bahasa Arab (PBA) UIN Raden Intan Lampung dapat dilakukan melalui dua dimensi; pertama, teknik pembelajaran interaktif dari komponen bahasa Arab; dan kedua, teknik pembelajaran interaktif melalui keterampilan berbahasa Arab. Adapun teknik pembelajaran interaktif pertama, mencakup: teknik pembelajaran alkalimat al-mutaqothi'ah; al-kalimah almusalsalah; ta'bir al-kalimah alfabaiyyah; 'ardh al-shuwar almulawwanah; al-kalimah al-gharibah takhruj; dan al-kalimah al-mujawizah. Sementara teknik pembelajaran interaktif kedua, meliputi: maharat al-istima', alkalam, al-qira'ah, dan al-kitabah. Aktualisasi teknik pembelajaran interaktif maharat al-istima' terdiri dari ta'lim almuta'awin; talkhish al-maghza; istima' al-mutabadil; istima' al-aghani; istima' al-ma'alimat wa al-akhbar; dan istima' al-musykilat. Aktualisasi teknik pembelajaran inter-aktif maharat alkalam mencakup khibrat al-mutsirah; ta'bir al-ara' al-raisiyyah; tamtsiliyah; ta'bir al-mushawwar; yal'ab dawr almudarris; dan jidal al-fa'al. Aktualisasi teknik pembelajaran interaktif maharat al-qira'ah adalah al-qira'ah almuwajjahah; mudzakarat al-talamidz; alqira'ah al-jahriyah; akhdziyah alnushush; al-talkhish al-jama' $i$; dan tartib al-nushush. Sedangkan aktualisasi teknik pembelajaran interaktif maharat alkitabah meliputi musyarakat al-kitabah al-fa'alah, ta 'bir al-shuwar al-tahriri; almafahim al-raisiyah; kitabat al-nasyarat; kitabat al-ma'lumat; in'ikas almaudhu'at; danal- mudzakarat almuwajjahah. 


\section{DAFTAR PUSTAKA}

Abid Ahmad al-Hasyimi, al-Muwajjih alAmali Li Mudarris al-Lughah alArabiyah, Beirut: Muassasah alRisalah, 1983, Cet. Ke-3

Abdullah al-Ghani, Nashir dan Abdullah, Abdul Hamid, Usus I'dad al-Kutub al-Ta'limiyyah Li Ghairi alNathiqina Bi al-Arabiyyah, Dar alI'tisham, Tanpa Tahun

Abudin Nata, Paradigma Pendidikan Islam, Jakarta: Grasindo, 2001,

Ahmad, Abdu al-Qadir, Muhammad, Thuruq Ta'lim al-Lughah alArabiyah, al Qahirah: al-Maktabah al-Nahdhah al-Mishriyah, 1979, Cet.ke-1

Ahmad Tha'imah, Rusydi, Ta'lim alArabiyah Li Ghair al-Nathiqina Biha: Manahijuhu Wa Asalibuhu, Isesco, 1989

Ahmad Utsman, Abdu al-Rahman, Manahij al-Bahts al-Ilmi Wa Thuruq Kitabah al-Risalah alJami'iyyah, Sudan: al-Khartum, 1995, Cet. Ke-1

Ali al-Khuli, Muhammad, Asalib Tadris al-Lughah al-Arabiyyah, Riyad: alMamlakah al-Arabiyyah alSu'udiyyah, 1982, Cet. Ke-1

Ali al Sayyid, Amin, Fi 'Ilmi al Nahwi, al Qahirah : Dar al Ma'arif, 1977,Cet. Ke-4,Jilid,1

Ali Ibn Muhammad al-Jarjani, al-Syarif, Kitab al-Ta'rifat, SingapuraJeddah: al-Haramain, Tanpa Tahun

Anis, Ibrahim, et.al., al-Mu'jam alWasith, Qahirah: 1972, Cet.Ke-3

Al-Abrasy, 'Athiyah, Muhammad, Wa alTawany, Abu al-Futuh, al-Mujiz fi al- Thuruq al-Tarbawiyyah li Tadris al-Lughah al-Qaumiyah, alQahirah: al- Maktabah al-Nahdhah al-Misriyah, Tanpa Tahun.
Al-Basyir, Abdullah, Ahmad, Mudzakkirah fi Thuruq Tadris alLughah al- Arabiyah, Jakarta: Jami'ah al-Imam Muhammad Ibnu Su'ud al-Islamiyah, Tanpa Tahun, Tidak di Terbitkan.

Al-Khuli, 'Ali, Muhammad, Asalib Tadris al-Lughah al-Arabiyah, Riyad: alMamlakah al-Arabiyah alSu'udiyah, 1982, Cet. ke-1

Ahmad Fuad Efendy, Metodologi Pengajaran Bahasa Arab, Misykat: Malang, 2005

Al-Ghani, Abdullah, Nashir, wa Abdullah, Abdu al-Majid, Usus I'dad al-Kutub al-Ta'limiyah li Ghairi al-Nathiqin bi al-Arabiyah, Dar al-I'tisham, Tanpa Tahun. 